\title{
PENDIDIKAN KARAKTER MELALUI PROSES PEMBELAJARAN, OBJEK \\ DAN MODEL-MODEL BIOLOGI
}

\author{
Prodi Pendidikan Maria Waldetrudis Lidi \\ tika, Fakultas Keguruan dan Ilmu Pendidikan \\ Universitas Flores \\ Email: edelnaubogo@yahoo.co.id
}

\begin{abstract}
Abstrak
Tujuan pendidikan nasional adalah untuk menciptakan generasi unggul dan berkarakter yang dicapai melalui pendidikan karakter. Penanaman karakter kepada peserta didik dapat dilakukan melalui empat model, diantaranya adalah model integrasi. Model ini mengintegrasikan nilai-nilai karakter di dalam mata pelajaran. Biologi adalah mata pelajaran yang dapat dijadikan sebagai wahana pendidikan karakter. Integrasi pendidikan karakter dalam biologi dapat melalui proses pembelajaran biologi dan materi biologi sebagai model. Objek dan model-model biologi dapat menjadi wahana pembentukan, pengembangan dan pemantapan karater. Beberapa model biologi yang dapat dijadikan sebagai contoh untuk pendidikan karakter adalah metamorfosis, masyarakat semut, simbiosis mutualisme, simbiosis komensalisme, Carica papaya, Pinguin, manajemen sel bakteri dan famili Cactaceae.
\end{abstract}

Kata Kunci: Pendidikan karakter, proses pembelajaran, objek. dan model biologi

\section{Ahstract}

National education goals are to create a superior generation and character which can be achieved by character education. Building the learner's character can be done through four models, including the integration model. This model integrates the values of characters in the subject. Biology is a subject that can be used as a vehicle for character education. The integration of character education in biology is through the leaming process and the materials as a model. Objects and models of biology can be a vehicle for the formation, development and character stabilization. Some biological models that can be used as an example for character education are a metamorphosis, an ant society, symbiotic mutualism, symbiosis commensalism, Carica papaya, Pinguin, the management of bacterial cells and the family Cactaceae.

Keywords: Character education. the learning process, objects, and biological model

\section{PENDAHULUAN}

Kemerosotan moral menjadi topik penting yang selalu diperbincangkan dan diberitakan akhir-akhir ini. Berbagai kasus yang menyimpang dari nilai-nilai moral, akhlak dan etika dalam hidup bermasyarakat terjadi di Indonesia. Kasus pembunuhan, pemerkosaan, narkoba, pencurian, korupsi, kekerasan, dll yang selalu terjadi di Indonesia merupakan salah satu indikator kehancuran suatu bangsa. Lembaga pendidikan turut menjadi sorotan bukan hanya karena perannya sebagai wahana pengembangan karakter tetapi ketika kasus kekerasan pun terjadi dalam dunia pendidikan itu sendiri. Kasus kekerasan tidak hanya menimpa anak didik tetapi kini guru sebagai teladan dalam berperilaku dan bersikap pun turut menjadi korban dari tindakan kekerasan.

Karakter menjadi penentu utama kemajuan atau kehancuran suatu bangsa. Bangsa yang berkarakter mampu bertahan dari pengaruh budaya luar yang bersifat negatif, mampu bersaing dengan bangsa lain secara positif dan menjadi bangsa yang sejahtera dan bermartabat. Pentingnya penanaman dan pengembangan karakter telah disadari sepenuhnya oleh bangsa ini dengan terus menggalakkan berbagai program berbasis pendidikan karakter baik melalui lembaga keagamaan, lembaga sosial dan lembaga-lembaga pemerintahan. Berdasarkan hasil kajian Ruyadi (2010), pendidikan karakter dalam kurikulum sekolah diperkenalkan pertama 
kali pada kurukulum 1947 sebagai mata pelajaran tersendri, selanjutnya pada kurikulum 1964 disatukan menjadi pelajaran agama, kurikulum 1968 pendidikan karakter dihilangkan, kemudian pada kurikulum 1975 muncul sebagai mata pelajaran pendidikan moral pancasila (PMP) dan mata pelajaran agama. Kurikulum 1984 pendidikan karakter hilang dan pada kurikulum 1994 dan KTSP 2006 pendidikan karakter kurang mendapat perhatian.

Menyadari berbagai permasalahan yang timbul akibat penyimpangan perilaku dari nilainilai moral yang terjadi saat ini, pemerintah melalui bidang pendidikan secara tegas menanamkan pendidikan karakter dalam kurikulum sekolah dari tingkat dasar hingga perguruan tinggi. Kurikulum 2013 sebagai kurikulum baru hasil revisi dari kurikulum KTSP secara eksplisit menekankan pendidikan karakter melalui hasil belajar ranah sikap. Ranah sikap juga perlu untuk dibelajarkan dan dievaluasi selain ranah kognitf dan ranah keterampilan. Hal ini mengingat pada kurikulum sebelumnya ranah sikap kurang mendapat perhatian.

Sekolah sebagai wahana pengembangan karakter berperan penting untuk menanamkan dan mengembangkan karakter peserta didik yang belum atau tidak diperoleh peserta didik dalam lingkungan keluarga dan masyarakat melalui proses pembelajaran baik di dalam kelas maupun di luar kelas. Pendidikan karakter dapat diintegrasikan dalam mata pelajaran-mata pelajaran di sekolah atau dapat diberikan secara khusus pada mata pelajaran tertentu, akan tetapi model apa pun yang digunakan tetap membutuhkan keahlian dan keterampilan dari guru dalam perencanaan, pelaksanaan dan evaluasi pembelajarannya.

\section{Pendidikan Karakter}

Machin (2010) menyatakan bahwa karakter terkait dengan pemahaman (Head), peduli (Heart), dan bertindak atas nilai etik utama (Hand). Dengan demikian, pendidikan karakter semestinya menyentuh tiga aspek di atas ( Head, Heart, Hand) melalui pembiasaan. Menurut Lepiyanto (2011), karakter adalah cara berpikir dan berperilaku yang menjadi ciri khas tiap individu untuk hidup dan bekerjasama, baik dalam lingkup keluarga, masyarakat, bangsa dan negara. Sejalan dengan kedua pendapat di ats Budimansyah karakter sebagai nilai-ni2, mendefenisikan nilai kebajikan, mau berbil kebajikan (tahu nyata berkehidupan baik) yan baik, dan nya diri dan terjawantahkan daly perilaku.

Menurut Lickona (dalam Sudraját (2011) pendidikan karakter adalah suatu usaha yang disengaja untuk membantu seseorang sehingga ia dapat memahami, memperhatikan, dan melakukan nilai-nilai etika yang inti. Pendidikan karakter oleh Lickona diperjelas oleh Sudrajar yang menyatakan bahwa pendidikan karakter melibatkan pengetahuan (moral knowing). perasaan (moral feeling) dan tindakan (mriral action) sehingga pada pendidikan karakter, guru harus mengikat para siswa dengan kegiatankegiatan yang mengantarkan siswa untuk berpikir kritis tentang persoalan etika dan moral. menginspirasi mereka untuk setia dan loyal dengan tindakan-tindakan etika dan inoral; dan memberikan kesempatan kepada mereka untuk mempraktikkan perilaku etika dan moral tersebut.

Menurut Zubaedi (2011). pendiditan karakter dipahami sebagai upaya penanaman kecerdasan dalam berpikir, penghayatan dalam bentuk sikap, dan pengalaman dalam bentuk. perilaku yang sesuai dengan nilai-nilai lutur yang menjadi jati dirinya, diuujudkan dalam interaksi dengan Tuhannya, diri sendiri. antar sesama, dan lingkungannya. Kesuma. Triatna. dan Permana (2011) secara lebih khusus mendefenisikan pendidikan karakter dalam seting sekolah sebagai "pembelajaran yang mengarah pada penguatan dan pengembangan perilahu perilaku anak secara utuh yang didasarhan pada suau nilai tertentu yang dirujuk oleh sekolah".

Berdasarkan hasil penelitian, Mulvatinigsih (2011) menyimpulkan bahwa model pendidikan karakter dapat disesuaikan dengan jenjang usia yaitu pada usia anak-anak bertujuan untuk pembentukan karakter melalui kegiatan bermain peran, bercerita, dll., pada usia remaja bertujuan untuk pengembangan karakter melalui
pengintegrasian dalam berbagai kegiatan
pembelajaran. poster, dll, peraturan sekolah, ekstrakurikuler. berujuan., sedangkan pada usia dewasa pemantapan karakter melaui 

pengajian. seminar, penulisan kana ilmiah.
evaluasi diri,dll.

Menurut Kesuma, Triatna, dan Permana (2011). intemalisasi pendidikan karakter dalam seting sekolah bertujuan untuk:

a. menguatkan dan mengembangkan nilai-nilai kehidupan yang dianggap penting dan perlu sehingga menjadi kepribadian/kepemilikan peserta didik yang khas sebagaimana nilainilai yang dikembangkan;

b. mengoreksi perilaku peserta didik yang tidak bersesuaian dengan nilai-nilai yang dikembangkan oleh sekolah;

c. membangun honeksi yang harmoni dengan keluarga dan masyarakat dalam memerankan tanggung jawab pendidikan karakter secara bersama.

\section{Strategi dan Metode Pembelajaran Pendidikan Karakter}

Menurut Zubaedi (2011), penanaman nilainilai dalam dunia pendidikan formal di sekolah haruslah terus menerus diberikan agar terinternalisasi dan dapat diwujudkan dalam tindakan nyata. Oleh karena itu pendidikan karakter memerlukan model dan metode penyampaian yang dapat digunakan untuk proses penanaman nilai tersebut. Terdapat empat tawaran model penyampaian pendidikan karakter. vaitu:

\section{Model Sebagai Mata Pelajaran Tersendiri}

Dalam model ini pendidikan karakter dijadikan sebagai sebuah mata pelajaran tersendiri. Guru bidang studi pendidikan karakter harus mempersiapkan dan mengembanghan kurikulum, mengembangkan silabus, membuat RPP, metodologi pembelajaran, dan evaluasi pembelajaran. Kelebihan model ini adalah materi yang disampaikan menjadi lebih terencana matang dan lebih terukur. Namun, model ini hanya melibatkan guru bidang studi saja sehingga pendidikan karakter seolah-olah hanya menjadi tanggungjawab satu orang guru saja yang pada akhirnya pendidikan karakter akan gagal karena hanya mengisi intelektual siswa tentang konsepkonsep dan tidak menyentuh intemalisasi nilai tersebut.

\section{Model Integrasi}

Dalam model ini pendidikan karakter diintegrasikan dalam seluruh mata pelajaran sehingga pendidikan karakter menjadi tanggunglawab semua guru. Setiap guru dapat memilih materi pendidikan karakter yang sesuai dengan tema atau pokok bahasan bidang studi. Keunggulan model ini adalah setiap guru ikut bertanggungjawab akan penanaman nilai-nilai kepada semua siswa dan pemahaman akan nilainilai pendidikan karakter cenderung tidak bersifat informatif-kognitif, melainkan bersifat aplikatif sesuai dengan konteks pada setiap bidang studi. Dampaknya siswa akan lebih terhiasa dengan nilai-nilai yang sudah diterapkan dalam berbagai serting. Kelemahannya adalah pemahaman dan persepsi tentang nilai yang akan ditanamkan harus jelas dan sama bagi semua guru.

\section{Model di Luar Pengajaran}

Penanaman nilai-nilai hidup yang membentuk harakter juga dapat ditanamkan melalui kegiatan di luar pengajaran. Model ini lebih mengutamakan pengolahan dan penanaman nilai melalui suatu kegiatan untuk dibahas dan dikupas nilai-nilai hidupnya. Model ini dapat dilakukan oleh guru sekolah yang bersangkutan yang mendapat sampiran tugas atau dipercayakan pada lembaga di luar sekolah untuk melaksanakannya

Kelebihan model ini adalah anak mendapat nilai melalui pengalaman konkret. Pengalaman akan lebih tertanam dibanding sekadar informasi apalagi informasi yang bersifat monolog. Keterlibatan anak dalam menggali nilai-nilai hidup melalui model kegiatan ini lebih mendalam dan menggembirakan anak. Kelemahan model ini adalah tidak ada dalam struktur yang tetap dalam kerangka pendidikan dan pengajaran di sekolah. Dengan demikian, membutuhkan waktu lebih banyak baik bagi guru maupun anak untuk meluangkan waktu agar mendapatkan nilai-nilai hidup tersebut. Model ini menuntut kreativitas dan pemahaman akan kebutuhan anak secara mendalam, tidak hanya sekadar ada acara belaka oleh karena itu dibutuhkan pendamping yang kompak dan mempunyai persepsi yang sama.

\section{Model Gabungan}

Model gabungan berarti menggunakan gabungan antara model terintegrasi dan model di luar pelajaran. Penanaman nilai dilakukan pengajaran formal terintegrasi bersamaan dengan kegiatan di luar pelajaran. Model ini dapat 
dilaksanakan baik dalam kerjasama dengan tim oleh guru dalam kerjasama dengan pihak di luar sekolah. Keunggulan model ini adalah bahwa semua guru terlibat dan bahtan dapat dan harus mau belajar dari pihak luar untuk mengembangkan diri siswa. Anak mengenal nilai-nilai hidup untuk membentuk pekerti yang mereka dapat secara informatif dan diperkuat dengan pengalaman melalui kegiatan-kegiatan yang terencana dengan baik. Kelemahan model ini adalah menuntut keterlibatan banyak pihak, banyak waktu untuk koordinasi, banyak biaya dan kesepahaman yang mendalam, terlebih apabila melibatkan pihak luar sekolah. Selain itu, lidak semua guru mempunyai kompetensi dan keterampilan untuk penanaman nilai ini. Hal ini harus diakui dan diterima sebagai kenyataan.

Selain model penyampaian, metode penyampaian perlu mendapat perhatian karena apabila tidak tepat, tujuan yang akan dicapai pun sulit untuk diperoleh. Metode menyangkut cara pendekatan dan penyampaian nilai-nilai hidup yang akan ditawarkan dan ditanamkan dalam diri anak. Beberapa metode yang dapat ditawarkan atau digunakan untuk pendidikan karakter, antara lain:

\section{Metode Demokratis}

Metode ini menekankan pencarian secara bebas dan penghayatan nilai-nilai hidup dengan langsung melibatkan anak untuk menemukan nilai-nilai tersebut dalam bimbingan guru.

\section{Metode Pencarian Bersama}

Metode ini menekankan pada pencarian bersama yang melibatkan siswa dan guru melalui diskusi atas soal-soal aktual dalam masyarakat, di mana dari proses ini diharapkan anak dapat mengambil nilai-nilai hidup dari masalah yang diolah bersama.

\section{Metode Siswa Aktif}

Metode ini menekankan pada proses yang melibatkan anak sejak awal pembelajaran. Guru memberikan pokok bahasan dan anak dalam kelompoknya mencari dan mengembangkan proses selanjutnya.

\section{Metode Keteladanan}

Metode ini dilakukan dengan menempatkan diri sebagai idola dan panutan bagi anak. Dengan keteladanan pendidik dapat membimbing anak untuk membentuk sikap yang kukuh. Dalam konteks ini. dituntut ketulusan, keteguhan, dan sikap konsistensi hidup seorang guru.

Metode Live In

Mctode ini bertujuan agar anak mempunyai pengalaman hidup bersama orang lain secara langsung dalam situasi yang sangat berbeda dari kehidupan sehari-harinya. Melalui pengalaman langsung anak dapat mengenal lingkungan yang berbeda dengan cara berpikir, tantangan, permasalahan, termasuk tentang nilai-nilai hidupnya.

\section{Metode Penjernihan Nilai}

Metode ini dilakukan dengan dialog aktif dalam bentuk sharing atau diskusi mendalam dan intensif sebagai pendampingan agar anak tidak mengalami pembelokan nilai hidup. Anak diajak untuk secara kritis melihat nilai-nilai hidup yang ada dalam masyarakatnya dan bersikap terhadap situasi tersebut. Metode ini penting sebab apabila ada bias tentang nilai dibiarkan dan seolah dibenarkan maka akan terjadi kekacauan pandangan dalam hidup bersama.

\section{Pendidikan Karakter Diintegrasikan dalam Proses Pembelajaran Biologi}

Penanaman dan pembentukan yang hanya dibebankan pada mata pelajaran agama dan Pancasila dan Kewarganegaraan tidaklah cukup, pengembangan karakter peserta didik perlu melibatkan lebih banyak mata pelajaran, bahkan semua mata pelajaran. Nilai-nilai pendidikan karakter dimasukkan dalam pembelajaran di kelas baik materi maupun proses pembelajarannya (Khusniati, 2012).

Ghufron (2010), integrasi nilai-nilai karakter dapat diintegrasikan dalam semua mata pelajaran yaitu pada kegiatan pembelajaran. Pendidikan karakter dapat dilakukan pada tahap-tahap; pendahuluan, kegiatan inti, dan penutup. Ditambahkan oleh Julaiha (2014), penyelenggaraan pendidikan karakter dalam pembelajaran seharusnya harus dilakukan dari tahap perencanaan, pelaksanaan dan evaluasi pembelajaran. Tahap perencanaan mencakup identifikasi kebutuhan, identifikasi kompetensi dan penyusunan program pembelajaran (Silabus dan RPP). Tahap pelaksanaan mencakup hegiatan 
Pendahuluan, hexiatan inti dan penutup. Tahap guru memberihan penilaian bendasa tahap ini tertentu. Penilain harus mem berdasarkan kriteria yaitu ramah pengetahuan, sikap dan hetiga ranah

Pencrapan pendidikan dan keterampilan. model integrasi di seholah dapat diteraphan dengan mata pelajaran biologi. Hal in diteraphan pada hasil penelitian sebelumn a dapat dilihat dari Machin mengintegrasikan olch Machin (2010). dalam proses pembelajaran pendidikan karakter hasil penelitiannya diketahui balogi. Berdasarkan pelajaran biologi selain peseta bahwa dalam mata sepenuhnya konsep dan mesta didik memahami memecahkan suatu permasalahar packanna untuk sama melatih peserta didil. pada saat yang hchuaan Tihan untuk menghargai pendidih an harahter penciptaan. Pengintegrasian pam materi pertumbuhan tanaman berpengaruh positif terhadap hasil belajar kognitif, afektit dan psikomotor

Selain itu, melalui keterampilan proses dalam pembelajaran biologi, karakter yang diharapkian seperti hetelitian, rasa ingin tahu, tcliti, jujur, sopan, menghargai pendapat orang lain, hemampuan berkomunihasi, disiplin, taat aturan, herja heras, dll muncul selama pembelajaran biologi.

Hal ini didukung oleh lepiyanto (2011). berdasarhan hasil kajiannya menyimpulhan bahwa pendidikan karakter juga dapat diintegrasikan dalam materi biologi yaitu pada materi pencernaan manusia. Nilai karakter yang terkandung dalam materi ini adalah kerjasama, tanggung jawab, berani, percaya diri dan kreatif.

Khusmiati (2012), pendidihan karakter dapat dikembangkan dalam pembelajaran IPA, salah satunya yaitu menggunakan pendekatan kontekstual. Pendidikan karakter diintegrasikan dalam proses pembelajaran mulai dari tahap perencanaan, pelaksanaan dan evaluasi pembelajaran. Pada dasarnya pembelajaran kontekstual merupakan konsep pembelajaran yang membantu guru dalam mengaitkan materi pelajaran dengan kehidupan nyata siswa, dan memotivasi siswa membuat hubungan antara pengetahuan yang dipelajarinya dengan kehidupan mereka. Pembelajaran kontekstual menerapkan sejumlah prinsip belajar yakni constructivism, questioning. inquiry. learning comimusity, nodeling, reflection and anthentic asse'ssment, di mana dalam prinsip-prinsip belajar terschut dapat dikembangkan berbagai karakter. Pengembangan harakter dalam prinsip-prinsip belajar secara singhat dijelaskan sebagai berihut

a. Konstruktivisme (constructivism)

Konstruhtivisme merupakan landasan berpikir pendekatan kontekstual, yaitu pengetahuan dibangun olch manusia sedikit demi sedikit, dan hasilnya diperluas melalui konteks yang terbatas serta tidak sekonyong-konyong. Manusia harus mengontruksi pengetahuan itu dan memberi makna melalui pengalaman nyata. Siswa terlibat aktif untuk membangun pengetahuan untuk dirinya sendiri. Dalam prinsip kontruktivisme ini dapat dikembangkan karakter antara lain herlikir hritis dan logis, mandiri, cinta ilmu, rasa ingin tahu, menghargai orang lain, bertanggungjawab, dan percaya diri.

b. Bertanya (questioning)

Bertanya adalah suatu strategi yang digunakan secara aktif oleh siswa untuk menganalisis dan mengeksplorasi gagasan-gagasan. Pertanyaan-pertanyaan spontan yang diajukan siswa dapat digunakan untuk merangsang siswa betikir, berdiskusi, dan berspekulasi. Pembelajaran yang menggunakan pertanyaanpertanyaan untuk menuntun siswa mencapai tujuan belajar dapat mengembangkan berbagai karakter, antara lain berfikir kritis dan logis, rasa ingin tahu, menghargai pendapat orang lain, santun, dan percaya diri.

c. Inkuiri (inquiry)

Menemukan (inquiry) merupakan bagian inti dari kegiatan pembelajaran berbasis kontekstual. Pengetahuan dan keterampilan yang diperoleh siswa diharapkan bukan hasil mengingat seperangkat fakta-fakta, tetapi dari menemukan sendiri. Guru harus merancang kegiatan yang merujuk pada kegiatan menemukan (misalnya melalui kegiatan praktikum) apapun materi yang diajarkannya. Melalui inkuiri dapat dikembangkan berbagai karakter seperti berfikir kritis, logis, kreatif, dan inovatif, rasa ingin tahu, menghargai pendapat orang lain, santun, jujur, dan tanggung jawab.

d. Masyarakat Belajar (learning commumity) Masyarakat belajar adalah sekelompok siswa yang terikat dalam kegiatan belajar agar 
pendahuluan, kegiatan inti dan penutup. Tahap
evaluasi pembelajaran, di mana pada evaluasi pembelajaran, di mana pada tahap ini tertentu. Penilain harus memperdasarkan kriteria yaitu ranah pengetahuan, sikap dakan tiga ranah

Penerapan pendidikan model integrasi di sekolah karakter dengan mata pelajaran biologi. Hal i diterapkan pada hasil penelitian sebelumnat dilihat dari Machin mengintegrasikan oleh Machin (2010). dalam proses pembelajaran pendidikan karakter hasil penelitianya dikenan biologi. Berdasarkan pelajaran biola dalam mata sepenuhnya konsep dan meta didik memaham memecahkan suatu permasa manya untuk sama melatih pesenta didikang meserta didik untuk menghargai kekuatan Tuhan dan penciptaan. Pengintegrasian pendidikan karakter dalam materi pertumbuhan tanaman berpengaruh positif terhadap hasil belajar kognitif, afektif dan psikomotor.

Selain itu, melalui keterampilan proses dalam pembelajaran biologi, karakter yang diharapkan seperti ketelitian, rasa ingin tahu, teliti, jujur, sopan, menghargai pendapat orang lain, kemampuan berkomunikasi, disiplin, taat aturan, kerja keras, dll muncul selama pembelajaran biologi.

Hal ini didukung oleh Lepiyanto (2011). berdasarkan hasil kajiannya menyimpulkan bahwa pendidikan karakter juga dapat diintegrasikan dalam materi biologi yaitu pada materi pencernaan manusia. Nilai karakter yang terkandung dalam materi ini adalah kerjasama, tanggung jawab, berani, percaya diri dan kreatif.

Khusniati (2012), pendidikan karakter dapat dikembangkan dalam pembelajaran IPA, salah satunya yaitu menggunakan pendekatan kontekstual. Pendidikan karakter diintegrasikan dalam proses pembelajaran mulai dari tahap perencanaan, pelaksanaan dan evaluasi pembelajaran. Pada dasarnya pembelajaran kontekstual merupakan konsep pembelajaran yang membantu guru dalam mengaitkan materi pelajaran dengan kehidupan nyata siswa, dan memotivasi siswa membuat hubungan antara pengetahuan yang dipelajarinya dengan kehidupan mereka. Pembelajaran kontekstual menerapkan sejumlah prinsip belajar yakni constructivism, questioning. inquiry, learning community, modeling, reflection and authentic assessment, di mana dalam prinsip-prinsip belajar tersebut dapat dikembangkan berbagai karakter. Pengembangan karakter dalam prinsip-prinsip belajar secara singkat dijelaskan sebagai berikut:

a. Konstruktivisme (constructivism)

Konstruktivisme merupakan landasan berpikir pendekatan kontekstual, yaitu pengetahuan dibangun oleh manusia sedikit demi sedikit, dan hasilnya diperluas melalui konteks yang terbatas serta tidak sekonyong-konyong. Manusia harus mengontruksi pengetahuan itu dan memberi makna melalui pengalaman nyata. Siswa terlibat aktif untuk membangun pengetahuan untuk dirinya sendiri. Dalam prinsip kontruktivisme ini dapat dikembangkan karakter antara lain berfikir kritis dan logis, mandiri, cinta ilmu, rasa ingin tahu, menghargai orang lain, bertanggungjawab, dan percaya diri.

b. Bertanya (questioning)

Bertanya adalah suatu strategi yang digunakan secara aktif oleh siswa untuk menganalisis dan mengeksplorasi gagasan-gagasan. Pertanyaan-pertanyaan spontan yang diajukan siswa dapat digunakan untuk merangsang siswa befikir, berdiskusi, dan berspekulasi. Pembelajaran yang menggunakan pertanyaanpertanyaan untuk menuntun siswa mencapai tujuan belajar dapat mengembangkan berbagai karakter, antara lain berfikir kritis dan logis, rasa ingin tahu, menghargai pendapat orang lain, santun, dan percaya diri.

c. Inkuiri (inquiry)

Menemukan (inquiry) merupakan bagian inti dari kegiatan pembelajaran berbasis kontekstual. Pengetahuan dan keterampilan yang diperoleh siswa diharapkan bukan hasil mengingat seperangkat fakta-fakta, tetapi dari menemukan sendiri. Guru harus merancang kegiatan yang merujuk pada kegiatan menemukan (misalnya melalui kegiatan praktikum) apapun materi yang diajarkannya. Melalui inkuiri dapat dikembangkan berbagai karakter seperti berfikir kritis, logis, kreatif, dan inovatif, rasa ingin tahu, menghargai pendapat orang lain, santun, jujur, dan tanggung jawab.

d. Masyarakat Belajar (learning community) Masyarakat belajar adalah sekelompok siswa yang terikat dalam kegiatan belajar agar 
terjadi proses belajar lebih dalam. Semua siswa harus mempunyai kesempatan untuk bicara dan berbagi ide, mendengarkan ide siswa lain dengan cermat, dan bekerjasama untuk membangun pengetahuan dengan teman di dalam kelompoknya. Konsep ini didasarkan pada ide bahwa belajar secara bersama lebih baik dari pada belajar secara individual. Dalam masyarakat belajar terjadi komunikasi dua arah di mana seseorang memberi informasi yang diperlukan oleh teman bicaranya dan sekaligus meminta informasi yang diperlukan dari teman bicaranya. Karakter yang dapat dikembangkan adalah kerjasama, menghargai pendapat orang lain. santun, demokratis, patuh pada aturan sosial. dan tangung jawab.

e. Pemodelan (modeling)

Pemodelan adalah proses penampilan suatu contoh agar orang lain berpikir, bekerja dan belajar. Pada saat pembelajaran, sering guru memodelkan bagaimana agar siswa belajar. Guru menunjukkan bagaimana melakukan sesuatu untuk mempelajari sesuatu yang baru. Model dapat dirancang dengan melibatkan siswa. Pemodelan dapat menumbuhkan rasa ingin tahu, menghargai orang lain, dan rasa percaya diri.

f. Refleksi (reflection)

Refleksi dilakukan agar siswa memikirkan kembali apa yang telah mereka pelajari dan lakukan selama proses pembelajaran. Refleksi biasa dilakukan pada akhir pembelajaran melalui diskusi, tanya jawab, penyampaian kesan dan pesan, menulis jurnal, saling memberi komentar karya, dan membuat catatan pada buku harian. Refleksi dapat menumbuhkan kemampuan berpikir logis dan kritis, mengetahui kelebihan dan kekurangan diri sendiri, dan menghargai pendapat orang lain.

g. Penilaian otentik (authentic assessment)

Penilaian autentik sesungguhnya adalah suatu istilah yang diciptakan untuk menjelaskan berbagai metode penilaian alternatif. Berbagai metode tersebut memungkinkan siswa dapat mendemonstrasikan kemampuannya untuk menyelesaikan tugas dan memecahkan masalah. Penilain autentik dapat mengembangkan karakter kejujuran. tanggungjawab, menghargai karya, dan
prestasi orang lain, kedispilinan, dan cinta ilmu.

Secara lebih khusus berdasarkan hasil penelitiannya Sadia. Amyana. Muderawan (2013), menyimpulkan bahwa 1) model pembelajaran sains yang diprediksi berkontribusi secara signifikan terhadap pengembangan karakter siswa adalah model pembelajaran kooperatif, kontekstual, model pembelajaran berbasis masalah. model pemecahan masalah, model inkuiri, model sains-teknologimasyarakat, model pembelajaran portofolio. model pembelajaran berbasis proyek, dan model siklus belajar. 2) respon guru terhadap pendidikan karakter sangat positif untuh ditingkatkan intensitas dan kualitasnya melalui jalur pendidikan di sekolah.

\section{Pendidikan Karakter melalui Model-model} Biologi

Pendidikan karakter dapat diintegrasikan dalam biologi menggunakan materi biologi sebagai model. Menurut Prof. Muslimin Ibrahim dalam pidato penguhuhannya sebagai profesor tanggal 16 desember 2002. menyatakan bahwa substansi materi pelajaran (misalnya biologi) harus dapat menjadi wahana pembentukan budi pekerti dan akhlak. Berikut akan dijabarkan beberapa model-model biologi yang memiliki contoh yang relevan untuk pendidikan dan budi pekerti menurut Prof. Muslimin Ibrahim.

a. Metamorfosis

Metamorfosis adalah proses perubahan bentuk yang terjadi pada makhluk hidup yang sedang berkembang. Misalnya metamorfosis pada kupu-kupu. Telur menetas menjadi ulat yang aktif makan, lalu beurbah menjadi kepompong yang tidak makan, kemudian menjadi kupukupu yang cantik dan elok. Dari model tersebut ditunjukkan, seekor ulat yang rakus dan menyebabkan kerusakan pada tanaman sehingga dibenci orang. Ulat kemudian memasuki fase kepompong, dimana pada fase ini ulat tersebut tidak makan (puasa) lalu menjadi kupu-kupu. Kupu-kupu adalah model untuk orang yang takwa. Kupu-kupu hanya memakan makanan yag terpilih (nektar), yang keluar dari tubuh kupu-kupu adalah madu, kupu-kupu tidak menggoyangkan dahan 

itu menyirathan agar seseorang haruslah (halal), berhati-hati apa yang dimakannya diucaphannya dan tidak mena yang masalah di lingkungannya. menimbulkan

b. Manajemen Sel Bakteri

Di dalam sel bakteri hita dapat belajar tentang manajemen modern. Semua bagian sel bekerja sangat profesional sesuai fungsinya masingberlangsungnya tercipta sinergi berwujud keseluruhan. Di dalama proses sel secara dogma sentral sebagai sel kita mengenal juga yang baik. DNA yan model kepemimpinan merupakan molekul (perdapat di nukleus penentu semua proses (pemimpin) sebagai mengandung semua tubuh makhluk hiduncang bangun lengkap manusia misalnya pemilik sel itu. Pada mengandung seluna, molekul tersebut

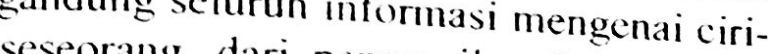
ciri seseorang, dari penampilan fisik sampai kepada struktur organ di dalam tubuhnya. Informasi di dalam DNA ini tercatat dengan sistem pengkodean khusus mengunakan tiga basa Adenin (A), Timin (T), Sitosin (S), dan Guanin (G). Molekul DNA di dalam suatu sel tidak pernah keluar dari istananya (inti sel), sebagai pemimpin tidak memonopoli semua pekerjaan, tetapi dia mengirimkan dutanya (RNA) ke bagian sel tertentu untuk menjalankan pesan-pesan yang diperintahkan. Pesan-pesan tersebut kemudian diterjemahkan dalam jenis-jenis protein yang menjalankan kerja seperti yang diinginkan oleh DNA tadi. Semua proses ini berlangsung dengan taat azas/taat hukum. Di dalam model biologi ini terdapat beberapa kunci untuk manajemen, yaitu taat hukum dan profesional, kaderisasi dan pendelegasian tugas. Terkandung unsur kejujuran, inovatif, terdapat pembagian tugas yang baik

c. Masyarakat Semut

Semut hidup secara sosial. Pada masyarakat semut terdapat pembagian tugas yang jelas. Semut-semut selalu berkomunikasi "mengucapkan salam" dengan cara mempertemukan kepalanya. Ketika seekor semut menemukan makanan maka ia akan menginformasikan makanan tersebut pada semut lain untuk kemudian dibawa bersamasama ke sarang mereka. Model biologi ini mengajarkan kita untuk tidak rakus tetapi hidup sosial dengan berbagi kepada sesama dan bergotong royong untuk kesejahteraan bersama. Semut juga menjadi model untuk memasyarakatkan kebiasaan memberikan salam. Dengan salam kita menjalin tali silaturahmi dan merupakan jalan untuk dapat saling mencintai sesama manusia.

Selain beberapa model biologi yang dijelaskan oleh Prof. Muslimin Ibrahim di atas kita juga dapat mempelajari karakter melalui model-model berikut ini.

d. Simbiosis Mutualisme

Interaksi atau simbiosis mutualisine adalah hubungan antar dua individu atau lebih yang saling menguntungkan dan saling membutuhkan. Melalui model biologi ini kita belajar asas keadilan, saling membantu dan bersatu untuk mencapai kesejahteraan bersama. Berbeda dengan interaksi parasitisme yang merugikan salah satu makhluk hidup. Satu pihak mengambil keuntungan dari pihak lain bahkan sampai merugikan.

e. Simbiosis Komensalisme

Simbiosis komensalisme adalah hubungan simbiosis yang menguntungkan satu spesies dan tidak merugikan atau menguntungkan spesies yang lain. Contoh Epifit adalah tumbuhan yang tumbuh di cabang-cabang tanaman lain. Secara umum, tanaman inang yang tidak terluka, sedangkan epifit yang tumbuh di atasnya menguntungkan. Misalnya Tumbuhan anggrek yang mendapatkan cahaya dan kelembapan dengan menempel pada pohon inang sedangkan pohon inang tidak dirugikan. Melalui model ini kita belajar untuk membantu orang lain dengan ikhlas dan tanpa pamrih

f. Pinguin Emperor

Pinguin merupakan hewan monogami. Seekor pinguin betina hanya dapat memiliki satu butir telur. Pinguin betina dan jantan akan bekerja sama dalam mengerami telur mereka. Pinguin jantan akan tetap mengerami telurnya selama pinguin betina berburu mencari makanan. Telur ditaruh di atas kaki pinguin jantan jadi 
sang jantan tidak akan bergerak atau diam agat telur tidak jatuh. Selama mengerami telurnya pinguin jantan lidak akan meninggalkan telurnya dan tidak mencari makan (berpuasa) sampai pinguin betinanya datang dan membawa makanan. Sclama berpuasa makanan ini tersimpan di tembolok sang jantan. Makanan ini disimpan bagi manakan pertama anaknya ketika menetas, sang jantan akan menyuapi bayinya dengan paruhnya.

Penguin emperor mengembangkan perilaku sosial yaitu mereka akan berkumpul bersamasama dalam kelompok untuk menjaga agar tubuhnya tidak kehilangan panas dalam jumlah yang banyak. Ada pergantian posisi, pinguin yang berada di bagian terluar kelompok akan perlahan-lahan menuju pusat kerumunan sehingga secara adil bergantian menghadapi dingin. Melalui model biologi ini kita belajar sabar, tahan uji, bekerja sama, peduli, kasih sayang dan rela berkorban

g. Tumbuhan Pepaya

Papaya (Carica papaya) merupakan tumbuhan yang banyak memiliki manfaal hagi kehidupan, salah satunya adalah manfaat dari buahnya selain sebagai organ pembawa keturunan. Buah pepaya dihasilkan melalui hasil penyerbukan antara serbuk sari dan putik yang berasal dari bunga yang sama (berumah satu). Ditemukan juga bunga pepaya yang tidak dapat menghasilkan buah akibat bunganya yang tidak sempurna (alat reproduksi tidak lengkap). Melalui model biologi ini kita mempelajari dua hal yaitu 1) dari tumbuhan pepaya yang menghasilkan buah ini kita dapat mempelajari karakter bekerja sama untuk kebaikan bersama, tanpa kerja sama kehidupan yang sejahtera sulit tercipta. 2) dari tumbuhan pepaya tanpa buah kita belajar, bahwa kekurangan yang kita miliki tidak menjadi penghambat utuk terus berjuang dan mendatangkan kebaikan bagi orang lain, seperti yang ditunjukkan oleh tumbuhan pepaya steril, yakni walaupun tidak menghasilkan buah tetap gigih untuk menghasilkan bunga yang juga mendatangkan manfaat bagi makhluk hidup lain yang menyukai bunganya sebagai sayuran. h. Tumbuhan Pada Ikosistem (iurun (I amili

( actacese)

Gurun terdapat di belahan bumi pada rentang 20-30 (' Lu dan Ls. Curah hujan di gurun rendah, yaitu kurang dari $25 \mathrm{~cm}$ per tahun. Kehidupan organisme di gurun beradaptasi dengan lingkungan yang kering. Vegetasinya terdiri dari berbagai belukar kaksia, tumbuhan sukulen, dan kaktus oleh karena itu tumbuhan ini melakukan adaptasi morfologi dan fisiologi tubuhnya untuk beradaptasi dengan lingkungan hidupnya yang ekstrim. Misalnya, kaktus akan memodifikasi daunnya menjadi duri untuk mengurangi penguapan air dari tubuhnya. Proses pengambilan $\mathrm{CO}_{2}$ van: diperlukan untuk proses fotosintesis melalui stomata dilakukan pada malam hari untuk mengurangi laju transpirasi. Stomata dibuka sekecil mungkin sehingga mengurangi kekurangan air oleh tubuh. Melalui model ini, kita belajar untuk mengenal kelebihan dan kekurangan diri kita. Kekurangan yang kita miliki seperti kemiskinan tidak menjadi penghambat untuk mencapai impian, seperti yang dimodelkan oleh kaktus (Famili (actaceae), walaupun miskin air kaktus tetap bertahan dan pandai dalam mengelola dirinya untuk bertahan hidup. Melalui kaktus pun kita belajar untuk berhemat seperti ungkapan Hemat Pangkal Kaya. Melalui prinsip hemat yang diterapkan kaktus, kaktus pada akhirnya dapat bertahan hidup bahkan berkembangbiak untuk mempertahankan jenisnya.

Selain model-model biologi yang telah dijelaskan di atas kita juga dapat belajar pantang menyerah dari rumput yang tidak berhenti tumbuh walaupun selalu dibasmi, belajar rendah hati dan disiplin dari kacang tanah, belajar disiplin dari ayam, belajar pantang menyerah dan rela berkorban dari ikan salmon, belajar kerjasama dari simbiosis bakteri rhizobium dan tanaman leguminase, dll. Model-model biologi yang dicontolikan di atas hanyalah beberapa contoh dari sekian banyaknya model biologi yang dapat kita gunakan dalam menanamkan dan mengembangkan pendidikan karakter. Biologi adalah salah satu model yang menyampaikan berbagai pesan berkarakter dalam kehidupan sosial, bermasyarakat dan bernegara. 


\section{PINUTUI'}

Pendidikan karakter dapat diintegrasikan dalam bologi melalui proses pembelajarannya hungya tahap evaluasiencanaan, pelaksanaan pendidikan karakter pembelajaran. Integrasi materi bologi schagal juga dapat menggunakan model biologi dapat ()bjek dan model pembentukan, pengemban menjadi wahana karakter. I)iharapkan melahi dan pemantapan cita-cita bangsa Indoncili pendidikan karakter sia yang tertuang dalam seutuhnya.

\section{IOAFTAR PISTIAKA}

(ihofur, A. 2010. "Integrasi Nilai-Nilai Karahter Bangsa pada Kegiatan Pembelajaran". Jurnal Cakrawala Pendidikan. Mei 2010, Ih XXIX, Edisi Khusus Dies Natalis UNY, Hal 13-24.

Julaiha, S. 2014. "Implementasi Pendidikan Karakter dalam Pembelajaran". Jurnal Dinamika I/mu. Vol 14, No.2, Desember 2014, Hal 226-239.

Kesuma, D., Triatna, C., dan Permana, J. 2011. Pendidikan Karakter (Kajian Teori dan Praklik di Sekolah). Bandung: PT. Remaja Rosdakarya.

Khusniati, M. 2012. "Pendidikan Karakter Melalui Pembelajaran IPA". .Jurncel Pendidikan IPA indonesia .JII I. (2) (2012) Hal 204-210.

Lepiyanto, A. 2011. "Membangun Karakter Siswa dalam Pembelajaran Biologi". Jurnal Bioedukasi, 2 (1), Hal 73-80.

Machin, A. 2014. "Implementasi Pendekatan Saintifik, Penanaman Karakter dan Konservasi Pada Pembelajaran Materi Pertumbuhan". Jurnal Pendidikan IPA Indonesia 3. (1) (2014) Hal 28-35.

Mulyatiningsih, E. 2011. Analisis Model-Model Pendidikan Karakter Untuk Usia Anakanak, Remaja dan Dewasa. (Diakses di uny.ac.id tanggal 10 september 2016).

Muslimin, 1. 2002. Dimensi Pendidikan dan Budi Pekerti Dalam Model-Model Biologi.
Pidato Pengukuhan Jabatan Gelar kehormatan Guru Besar Di Bidang IImu Biologi pada FMIPA Universitas Negeri Surabaya tanggal 16 Desember 2002 (on line).

Ruyadi, Y. 2010. "Model Pendidikan Karakter Berbasis Kearifan Budaya Lokal (Penelitian terhadap masyarakat adat kampung Benda kerep Cirebon Jawa Barat untuk Pengembangan pendidikan Karater di sekolah)". Proceedings of the $4^{\text {th }}$ International Conference on Teacher Education; Join Conference UPI \& UPSI. Bandung, Indonesia 8-10 November 2010, Hal 576-594.

Sadia, Arnyana, Muderawan. 2013. "Model Pendidikan Karakter Terintegrasi Pembelajaran Sains". Jurnal Pendidikan Indonesia. Vol 2, No.2, Oktober 2013, Hal 209-220.

Sudrajat, A. 2011. "Mengapa Pendidikan Karakter?". Jurnal Pendidikan Karakter. Tahun I, No 1, Oktober 2011 UNY, Hal 47-58

Lubaedi. 2011. Desain Pendidikan Karakter (Konsepsi dan Aplikasinya dalam Lembuga Pendidikan). Jakarta: Kencana Prenada Media Group.

Majalah Ilmiah Indikator

Volume $X X$. Nomor I, Maret 2017. ISSN 1411 707X 